M. A. Kholiq. Kontroversi Hukuman... 185

\title{
Kontroversi Hukuman Mati Dan Kebijakan Regulasinya Dalam RUU KUHP (Studi Komparatif Menurut Hukum Islam)
}

\author{
Oleh: M. Abdul Kholiq \\ Dosen FH UII Yogyakarta \\ E mali:
}

\begin{abstract}
Abtract
The existence of death penalty as a criminal sanction always raises controvertial. Using a comparative study method, this study concludes that : firstly, the existence of death penalty in the draft of Indonesian Criminal Code is to protect the society and to protect the right to live which becomes non-derogable righs. It was designed for specific crime, and it is implemented selectively; secondly, the prohibition of execution before the publict has to be changed and to be reviewed. This mechanism will create an obtacle to achieve the objective of this sanction.
\end{abstract}

Keywords: Kontroversi, Hukuman Mati, dan Tata Cara Eksekusi

\section{Pendahuluan}

Dalam komunitas hukum maupun kalangan masyarakat umum, fenomena pro dan kontra tentang masalah pidana mati bukanlah hal yang baru. Meskipun bersifat temporer, polemik mengenai hal ini biasanya akan selalu muncul setiap kali ada penjatuhan pidana mati oleh pengadilan atau ada eksekusi terhadap putusan pidana tersebut.

Pada era 1980-an, pidana mati yang dijatuhkan kepada Kusni Kasdut telah sedemikian rupa menarik perhatian publik. Demikian juga pada 1990-an, masyarakat pun seolah tersedot energinya karena mendiskusikan kejahatan sadis oleh Karta Cahyadi dan Tugiman yang akhirnya mendorong majelis hakim Pengadilan Negeri Surakarta waktu itu untuk memvonis mati terhadap mereka.

Awal abad millenium (2000-2007) ini, para ahli hukum dan masyarakat awam pun kembali terlibat debat panjang tentang eksekusi atas Ayodya (terpidana mati kasus Narkoba), Astini (terpidana mati kasus pembunuhan mutilasi), Tibo (terpidana mati kasus kerusuhan Poso) dan 
terakhir kasus Bahar Mattar yang sudah menunggu dan tak kunjung pasti mengenai eksekusi pidana mati atas dirinya selama lebih dari 36 tahun di Lembaga Permasyarakatan Nusakambangan. Sebelumnya, polemik mengenai hal ini juga sempat mengemuka dalam kaitannya dengan rencana eksekusi pidana mati yang telah dijatuhkan putusannya oleh Pengadilan Negeri Surabaya hampir sembilanbelas tahun silam kepada Sugeng dan ibunya (Suryati) setelah permohonan grasinya ditolak Presiden.

Umumnya, sumber kontroversi berkisar pada perdebatan mengenai keabsahan pidana mati sebagai sanksi hukum dan efektifitas/ kemampuannya sebagai pengendali kejahatan dalam kenyataan. Bahkan tidak jarang pula perdebatan tersebut pun dikaitkan dengan perspektif hak asasi manusia (HAM) serta doktrin agama yang antara lain mengajarkan bahwa hidup dan matinya makhluk adalah mutlak berada dalam wilayah hak Tuhan sebagai sang Khaliq (Pencipta). Bukan manusia (penguasa), sekalipun atas nama hukum.

Berdasar adanya kontroversi yang terus menerus ini, maka dalam (Rancangan Undang-Undang Kitab Undang-Undang Hukum Pidana) nasional yang dirancang sebagai salah satu wujud pembaharuan hukum pidana Indonesia, pidana mati tidak lagi ditempatkan sebagai pidana pokok bersifat umum, tetapi menjadi pidana khusus yang eksepsional. Politik hukum yang demikian ini memang tidak lepas dari konstruksi hukum pidana Indonesia mendatang yang dikehendaki berbasis pada ide Keseimbangan Mono-Dualistik atau Daad-Daader Strafrecht. Ini berarti bahwa hukum pidana memperhatikan secara seimbang antara hak/ kepentingan masyarakat luas/negara (termasuk korban) pada satu sisi, dan hak/kepentingan individu pelaku kejahatan (offender) sebagai manusia pada sisi yang lain. ${ }^{1}$

Bertolak dari hal-hal di atas, maka membicarakan kontroversi hukuman mati kiranya cukup relevan untuk disimak lebih dahulu pemikiran-pemikiran apa yang melatar belakangi adanya kontroversi tersebut. Paparan pemikiran mengenai kontroversi ini tentu tidak dimaksudkan untuk memperpanjang daftar barisan dari salah satu di antara dua kelompok pro dan kontra yang ada di masayarakat. Akan

\footnotetext{
${ }^{1}$ Barda Nawawi Arief, "Pokok-Pokok Pemikiran (Ide Dasar) Asas-Asas Hukum Pidana Nasional," makalah dalam Seminar Nasional tentang Asas-Asas Hukum Pidana Nasional, Diselenggarakan oleh BPHN Departemen Kehakiman dan HAM RI Jakarta bekerjasama dengan Fakultas Hukum UNDIP Semarang, 26-27 April 2004.
} 
tetapi diperlukan untuk mendeskripsikan dan menyelami mengapa pidana mati selalu diperdebatkan orang.

Setelah itu, baru kemudian akan dicermati bagaimana RUU KUHP mendatang menuangkan kebijakan pengaturannya dalam merespon kontroversi tadi. Selanjutnya untuk memperoleh hasil kajian yang sedikit lebih komprehensif tulisan ini akan berusaha pula mengkomparasikan pencermatan kebijakan pengaturan tentang pidana mati dalam RUU KUHP tersebut melalui sudut pandang (perspektif) hukum pidana Islam.

\section{Pemikiran-Pemikiran Pro dan Kontra}

Sebagaimana telah dikemukakan di atas, bahwa perdebatan seputar kontroversi tentang pidana mati biasanya terlihat pada dua kelompok argumen yakni pro dan kontra yang bersifat dikhotomis dan seolah sulit dipertemukan.

Dalam perspektif sejarah, eksistensi pidana mati sebagai sanksi hukum sesungguhnya sudah lama dikenal dalam tata kehidupan manusia. Baik pada jaman Yunani kuno, Romawi, Jerman maupun Kanonik. Pada saat itu terutama di jaman Imperium Romawi, pelaksanaan pidana mati dilakukan dengan cara-cara yang menurut ukuran kemanusiaan sekarang sungguh terkesan sangat kejam. Misalnya terpidana diikat pada suatu tiang lalu dibakar hidup-hidup, atau dimasukkan ke dalam kandang singa/macan yang kelaparan, atau diikat dan kemudian ditarik oleh empat kuda yang berlari dengan kekuatan penuh ke arah yang berlainan hingga tubuh terpidana tercerai berai, atau ditenggelamkan ke dasar laut dan lain sebagainya. Namun pada sekitar akhir abad XVII dan permulaan abad XVIII, ancaman dan pelaksanaan sanksi pidana mati terlihat mulai banyak dihindari oleh sejumlah negara karena adanya kritik tajam dari para ahi hukum pidana yang menentangnya. ${ }^{2}$

Voltaire misalnya, berpandangan bahwa hendaknya penjatuhan pidana mati dibatasi. Karena ia memiliki pengalaman menarik dalam penanganan kasus terpidana mati bernama Callas di mana setelah dieksekusi, muncul keraguan publik bahwa pelaku kejahatan yang patut dihukum mati sesungguhnya bukan Callas. Setelah terjadi pemeriksaan ulang terhadap

${ }^{2}$ Andi Hamzah, Sistem Pidana dan Pemidanaan Indonesia, Pradnya Paramita, Jakarta, 1993, hlm. 11. Gambaran lebih detail mengenai praktik pelaksanaan pidana mati dalam lintasan sejarah tersebut (terutama di Indonesia), dapat pula dibaca tulisan Andi Hamzah dan Sumangelipu, Pidana Mati di Indonesia di Masa lalu, Kini dan Di Masa Depan, Ghalia Indonesia, Jakarta, 1984. 
perkara, ternyata Callas memang tidak terbukti bersalah sebab pelaku kejahatan yang sebenarnya telah diketemukan dan mengakui perbuatannya. Namun hal tersebut tidak ada gunanya, karena Callas sudah terlanjur mati. Secara filosofis, Cesare Becaria bahkan mempersoalkan apakah negara sungguh-sungguh memiliki hak untuk menjatuhkan pidana mati pada warga?

Alasan utama penjatuhan pidana adalah untuk menjamin kelangsungan hidup masyarakat dan untuk mencegah orang melakukan kejahatan. Kenyataannya, pidana mati tidak mampu mencegah kejahatan tetapi justru lebih mencerminkan sebuah kebrutalan. Dalam pandangannya, seseorang tidak dapat mengorbankan kehidupannya sendiri, sehingga oleh karena itu tidak ada pula seorang pun yang dapat memberikan suatu kehidupan (hak hidup) ataupun kematian (hak mati) kepada sesamanya. Karena hidup adalah hak paling dasar yang dimiliki setiap manusia secara kodrati sebagai anugrah/pemberian Tuhan Yang Maha Esa. ${ }^{3}$

Dalam perkembangan, kalangan kontra pidana mati yang populer disebut kaum abolisionis ini, umumnya mendasarkan alasan-alasan penolakannya pada dalil-dalil sebagai berikut:

1. Pidana mati hakekatnya merupakan pelanggaran HAM paling esensial karena hidup adalah hak milik setiap manusia yang merupakan anugerah/pemberian Tuhan paling dasar. ${ }^{4}$

2. Pidana mati telah menghilangkan sama sekali kesempatan yang seharusnya dimiliki setiap orang untuk memperbaiki diri dari suatu kesalahan atau kejahatan yang pernah/terlanjur diperbuat ${ }^{5}$

3. Berbagai metode tentang cara eksekusi pidana mati yang telah dikembangkan selama ini (seperti disuntik, disetrum listrik, ditembak, dipenggal kepala dan lain-lain), masih tetap mencerminkan sifat tidak manusiawi sekaligus sebagai suatu bentuk pelanggaran HAM ${ }^{6}$

\footnotetext{
${ }^{3}$ Cesare Beccaria sebagaimana dikutip oleh Soedarto dalam tulisannya berjudul Suatu Dilemma dalam Pembaharuan Sistem Pidana Indonesia, Kumpulan Pidato Pengukuhan Guru Besar Fakultas Hukum, UNDIP, Semarang, Badan Penerbit Universitas Diponegoro, Semarang, 1994, hlm. 22.

${ }^{4}$ Soetandyo Wignjosoebroto, "Penerapan Pidana Mati: Sebuah Kontroversi dari Perspektif Hak-Hak Asasi Manusia," makalah dalam Simposium Nasional bertema Perspektifterhadap Pidana Mati di Indonesia, diselenggarakan oleh Pusat Kajian Sistem Peradilan Pidana Fakultas Hukum Universitas Tujuh Belas Agustus (UNTAG) Semarang, 14 Agustus 2003

${ }^{5}$ Adnan Buyung Nasution dalam Muhadi Zainal, Pidana Mati Dihapuskan atau Dipertahankan?, Hanindita Offset, Yogyakarta, 1984, hlm. 28

${ }^{6}$ Roeslan Saleh, Masalah Pidana Mati, Aksara Baru, Jakarta, 1978, hlm. 28-30.
} 
4. Bila terjadi kesalahan dalam penjatuhan dan pelaksanaan pidana mati maka akan menimbulkan kesulitan luar biasa untuk merubah/ memperbakinya;

5. Dalam realitas, penjatuhan dan pelaksanaan pidana mati ternyata tidak menjamin/kurang signifikan sebagai alat pengendali kejahatan, sekalipun terhadap kejahatan-kejahatan serius yang diancam dengan pidana mati itu sendiri. ${ }^{7}$

Sementara itu bagi kelompok yang pro dan tetap ingin mempertahankan eksistensi pidana mati yang biasa disebut kaum retensionis, mereka berargumentasi bahwa:

1. Dalam perspektif religious law, Tuhan sebenarnya telah mendelegasikan kepada manusia melalui firman-firman-Nya dengan memerintahkan agar pidana mati dijatuhkan dan dilaksanakan dalam kasus-kasus tertentu untuk menjaga keseimbangan dan ketertiban kehidupan bersama. Delegasi Tuhan ini misalnya tercermin pada kitab suci al-qur'an surat al-Baqarah: 178, al-Isra': 31 dan lain-lain. Adanya doktrin delegasi ini sesungguhnya mengandung makna bahwa penjatuhan dan pelaksanaan pidana mati bukanlah merupakan pelanggaran terhadap pemilik hak hidup hakiki yaitu Tuhan ${ }^{8}$;

${ }^{7}$ Calvin Smid sebagaimana dikutip oleh Suparman Marzuki dalam makalahnya berjudul "Pro Kontra terhadap Hukuman Mati," menyatakan bahwa hukuman mati di Asia dan Afrika terbukti tidak signifikan dalam menekan kejahatan sadis. Atau dengan kata lain tidak punya efek prevensi general. Hal ini disebabkan karena masyarakat di Negara-negara pada dua benua tersebut umumnya cenderung lebih memikirkan bagaimana mengatasi masalah kemiskinan yang mereka derita daripada hukuman yang harus dijalani saat terlibat melakukan suatu kejahatan. Selengkapnya baca makalah di atas yang dipresentasikan dalam Seminar Regional bertema Kontroversi Hukuman Mati, diselenggarakan oleh Badan eksekutif Mahasiswa (BEM) Fakultas Hukum Universitas Ahmad Dahlan (UAD) Yogyakarta, 10 Mei 2003. Sikap senada juga ditunjukkan oleh J.E Sahetapy yang meragukan kemanfaatan pidana mati terutama dari sudut pandang kriminologi. Dia menyatakan bahwa eksistensi pidana mati tidak mampu menjelaskan mengapa meskipun ia ada, orang masih terus saja melakukan kejahatan. Bahkan dia berpandangan pula bahwa semakin sering pidana mati diancamkan terhadap berbagai macam jenis kejahatan, yang akan terjadi adalah berlakunya hukum ekonomi bernama "Gossen". Artinya akan semakin berkurang rasa takut orang terhadap hukuman mati tersebut. Selengkapnya mengenai hal ini baca J.E Sahetapy, Suatu Studi Khusus Mengenai Ancaman Pidana Mati terhadap Pembunuhan Berencana, Rajawali, Jakarta, 1982, hlm. 216.

${ }^{8}$ Lihat pandangan Moh. Yamin mengenai hal di atas yang menyatakan bahwa hakim yang menjatuhkan pidana mati tidak dapat diartikan sebagai mengintervensi hak Tuhan. Justru dia menjadi wakil Tuhan dalam menegakkan keadilan dan 
2. Terjadinya kekeliruan (salah orang) dalam penjatuhan dan pelaksanaan mati, kemungkinannya adalah sangat kecil mengingat syarat untuk penerapan pidana ini tentu harus dengan pertimbangan yang sangat matang dan hati-hati. Karena pidana mati merupakan sanksi hukum paling berat sehingga penggunaannya tidak boleh sembarangan;

3. Diperlukan suatu persepsi yang berimbang untuk memahami adanya aspek berupa kurang/tidak manusiawinya sanksi pidana mati, yakni dengan cara membandingkan pula, betapa tidak manusiawinya perbuatan terpidana terhadap korbannya pada saat ia melakukan kejahatan. Walaupun hal ini terkesan retributif (pidana sebagai pembalasan) ${ }^{9}$;

4. Naik turunnya angka kejahatan atau terkendalinya kejahatan sebagai fenomena sosial adalah berkait dengan multi faktor. Sedangkan hukum pidana ( melalui pidana mati) hanyalah merupakan salah satu faktor saja. Dengan kata lain, penanggulangan kejahatan tidak dapat dibebankan semata hanya kepada/melalui fungsionalisasi hukum pidana saja. Disinilah relevansi perspektif politik kriminal yang mengajarkan bahwa mengingat keterbatasan-keterbatasan yang ada pada hukum pidana, maka upaya penanggulangan kejahatan mestinya dilakukan dengan menerapkan pendekatan integral antara sarana penal (yakni dengan membuat, menerapkan dan melaksanakan aturan hukum pidana secara konsisten) serta sarana non penal (yaitu dengan mengefektifkan penggunaan kebijakan-kebijakan di luar hukum pidana, seperti ekonomi, sosial, politik, budaya dan agama). ${ }^{10}$

ketertiban masyarakat yang digoncang oleh pelaku kejahatan. Untuk itu dasar peradilan adalah Demi Keadilan Berdasarkan Ketuhanan Yang Maha Esa Selengkapnya baca Majalah UNISIA edisi No. 4/XI Tahun 1989 dengan topik utama "Diskusi Hukuman Mati" Baca pula paparan mengenai hal ini oleh Bambang Poernomo, Ancaman Pidana Mati dalam Hukum Pidana di Indonesia, Liberty, Yogyakarta, 1982, hlm. 9

${ }^{9}$ Perdebatan cukup dalam mengenai aspek kemanusiaan dari penjatuhan dan eksekusi pidana mati yang dikaitkan dengan dimensi kemanusiaan pada korban kejahatan ini, dapat dibaca Muzayyanah, "Pidana Mati Ditinjau dari Pancasila," Artikel dalam Masalah-Masalah Hukum, Fakultas Hukum Universitas Diponegoro (UNDIP) Semarang, edisi No.2 Tahun 1991, hlm 11-12.

${ }^{10}$ M. Abdul Kholiq, Penjatuhan Pidana Mati dalam Rangka Penegakan Hukum dan Eksistensinya dalam Pembaharuan KUHP Nasional, Skripsi S-1, Fakultas Hukum UII Yogyakarta, 1991. 
Dalam perspektif teori, masalah keabsahan sebuah sanksi pidana (termasuk pidana mati) yang sering menimbulkan perdebatan tersebut, sesungguhnya juga disadari oleh para ahli hukum pidana sendiri. Leo Polak misalnya, dengan sinis pernah menyatakan :

"Hukum Pidana adalah bagian dari hukum yang paling celaka. Sebab sampai sekarang ini ia tidak pernah tahu mengapa ia disebut hukum. Kedengarannya memang keras, tetapi kita harus mengatakan hal itu dan menunjukkan bahwa ia tidak mengenal baik dasar maupun batasannya, baik tujuan maupun ukurannya. Berbagai problema atau mungkin satu-satunya problema dasar dari hukum pidana ialah apa sesungguhnya makna, tujuan serta ukuran dari penderitaan yang ditimbulkkan oleh suatu sanksi pidana yang benar-benar patut diterima oleh pelaku kejahatan? Hal ini tetap menjadi problema yang tidak terpecahkan". ${ }^{11}$

Problema keberadaan sebuah sanksi pidana seringkali juga dipersoalkan orang dengan mengkaitkan efektivitas kemampuannya dalam menanggulangi dan mencegah kejahatan (terutama yang bersifat general prevention). Atas dasar ini seringkali orang kemudian mudah berpandangan bahwa jika tujuan keberadaan dan penerapan pidana mati antara lain misalnya adalah untuk mencegah terulangnya kembali kejadian kasus-kasus pembunuhan sadis dan berencana atau kejahatan serius lainnya pada masa mendatang (pasca penerapan pidana mati), maka apabila dalam fakta, kasus-kasus tersebut ternyata masih sering terjadi, berarti pidana mati tidak efektif dan perlu digugat justifikasi keberadaannya. ${ }^{12}$

Pandangan seperti di atas meskipun logis, namun berkesan menyederhanakan persoalan (simplifistik). Sebab taat tidaknya seseorang

\footnotetext{
${ }^{11}$ Soedarto, Hukum dan Hukum Pidana, Alumni, Bandung, 1986, hlm. 23.

${ }^{12}$ Untuk memahami gugatan terhadap eksistensi hukuman mati sebagai sanksi pidana di atas, barangkali dapat dicermati pula fenomena seringnya ada penjatuhan pidana mati terhadap para pelaku kejahatan narkoba oleh Pengadilan Negeri Tangerang akhir-akhir ini. Meskipun demikian, fakta menunjukkan bahwa pada saat yang sama di wilayah Tangerang angka kejahatan tersebut justru meningkat. Bahkan di wilayah ini beberapa kali diberitakan tentang hasil operasi kepolisian yang cukup mengejutkan karena ternyata pabrik ekstasi terbesar di Asia pun ada di sana. Fakta ironis ini secara agak lengkap dapat dibaca antara lain dalam hasil penelitian M. Faisal, Penjatuhan Pidana Mati dan Pengaruhnya terhadap Tingkat Kejahatan Narkoba di Wilayah Hukum PN Tangerang, Skripsi S-1, Fakultas Hukum UII Y ogyakarta, 2006.
} 
atau masyarakat terhadap hukum sesungguhnya dipengaruhi oleh berbagai macam faktor yang sangat beragam. Tidak semata-mata karena kekuatan pengaruh sebuah sanksi hukum. Sekalipun itu oleh sanksi hukum yang paling keras yakni pidana mati. Terlebih lagi jika dalam praktek, eksekusi pidana mati di Indonesia berdasarkan UU No. 2 Tahun 1964 adalah tetap bersifat tertutup (baca: tidak dapat diakses/ditonton oleh publik). Jika demikian halnya maka bagaimana mungkin masyarakat bisa diharap mengambil pelajaran secara serius atas penegakan sanksi hukum yang tertutup tersebut ?. ${ }^{13}$ Model eksekusi pidana mati secara tertutup ini tampaknya juga masih akan dipertahankan dalam RUU KUHP mendatang. ${ }^{14}$

Soal efektifitas pidana dan pemidanaan tersebut, Karl O. Christiansen pernah menyatakan bahwa hal itu hakekatnya merupakan Terra in Cognita, yaitu sebuah persoalan yang memang tidak dapat diketahui atau diukur secara pasti. ${ }^{15}$ Oleh karena itu pula Donald R. Taft dan Ralph W. England bahkan menegaskan bahwa harus disadari, soal efektifitas hukum pidana memang tidak dapat diukur secara akurat. Hal ini karena hukum hanya merupakan salah satu sarana kontrol sosial. Kebiasaan, keyakinan agama, dukungan dan pencelaan kelompok penekan dari kelompok-kelompok interest serta pengaruh dari pendapat umum masyarakat, seringkali justru merupakan sarana-sarana yang lebih efisien dalam mengatur tingkah laku manusia dari pada sanksi hukum. ${ }^{16}$

Terlepas dari adanya perdebatan pro dan kontra mengenai pidana mati yang seolah tidak pernah berhenti tersebut, ada satu hal pasti yang perlu digaris bawahi ialah bahwa dalam sistem hukum pidana Indonesia yang berlaku sekarang ini pidana mati masih merupakan jenis sanksi hukum yang sah berlaku baik secara de yure maupun de facto.

${ }^{13}$ Bandingkan praktik eksekusi hukuman mati dalam Islam bernama qishash yang keabsahannya justru mensyaratkan harus dilihat/ditonton oleh masyarakat. Bahkan tidak hanya eksekusi pidana qishash. Eksekusi pidana cambuk dalam kejahatan zina juga diharuskan demikian. Perhatikan firman Allah SWT dalam Q.S An-Nuur ayat 2 terutama pada kalimat walyasyhad 'adzaabahuma thaa'ifatun minal mukminiena (terjemahan bebas: dan hendaklah sebagian golongan masyarakat mukmin lain menyaksikan pelaksanaan hukuman cambuk pada kedua pezina itu).

${ }^{14}$ Lihat Konsep Pasal 88 ayat (2) RUU KUHP yang menyatakan bahwa pidana mati sebagaimana dimaksud pada ayat (1) tidak dilaksanakan di muka umum.

${ }^{15}$ Karl O. Christiansen dalam Barda Nawawi Arief, Bunga Rampai Kebijakan Hukum Pidana, Citra Aditya Bhakti, Bandung, 2002, hlm. 229.

${ }^{16}$ Donald R. Taft dan Ralph W. England dalam Barda Nawawi Arief, PokokPokok ...op.cit., hlm. 227. 
Secara de yure, pidana mati kenyataannya belum dicabut dari berbagai ketentuan perundang-undangan pidana baik yang terdapat dalam KUHP maupun di luar KUHP. Sebagai stelsel pidana, keberadaan pidana mati masih dilegitimasi oleh pasal 10 huruf a KUHP. Oleh karena itu pidana mati pun tetap sah sebagai sanksi yang diancamkan pada berbagai kejahatan serius seperti makar dengan maksud membunuh presiden atau wakil presiden (pasal 104); mengajak negara asing menyerang Indonesia (pasal 111 ayat 2); membunuh kepala negara sahabat (pasal 140 ayat 1); pembunuhan berrencana (pasal 340); pencurian dengan kekerasan yang mengakibatkan matinya korban (pasal 365 ayat 4) dan sebagainya. Di luar KUHP, berbagai perundang-undangan juga memperlihatkan kecenderungan dipertahankannya pidana mati. Misalnya dalam kejahatan Narkotika (UU No.22 Tahun 1997) dan Psikotropika (UU No.5 tahun 1997), kejahatan korupsi (UU No.31 Tahun 1999 jo. UU No. 20 Tahun 2001), kejahatan HAM berat (UU No.26 Tahun 2000) dan kejahatan terrorisme sebagaimana termaktub dalam Perpu No.1 Tahun 2002 yang kemudian disahkan menjadi UU No.15 Tahun 2003.

Patut dikemukakan di sini bahwa meskipun pidana mati memang terlihat tetap dipertahankan dalam berbagai undang-undang di atas, namun politik pengancaman dan penjatuhannya sesungguhnya sangat selektif. Kebijakan ini setidaknya terlihat pada hal-hal sebagai berikut:

1. Pidana mati tidak pernah diancamkan terhadap suatu kejahatan secara sendiri. Akan tetapi selalu dialternatifkan dengan pidana penjara seumur hidup atau pidana penjara limitatif paling lama 20 (dua puluh) tahun. Oleh karena itu dalam perundang-undangan, bila suatu kejahatan dikenai ancaman pidana mati maka bunyi ancamannya adalah: “ ...diancam dengan pidana mati atau pidana penjara seumur hidup atau pidana sementara maksimum 20 tahun penjara ...

2. Penjatuhan pidana mati dalam KUHP prinsipnya selalu bersifat tunggal. Artinya tidak boleh berbarengan dengan penjatuhan pidana pokok lainnya seperti penjara, denda, kurungan atau tutupan. Sedangkan dalam perundang-undangan di luar KUHP, sepanjang telah diatur sebagai lex spesialis, memang dimungkinkan penjatuhan pidana mati secara ganda dengan pidana lainnya. Misalnya seperti ketentuan dalam UU No.31 Tahun1999 tentang Korupsi, UU No.5 Tahun 1997 dan No.22 Tahun 1997 tentang Psikotropika dan Narkotika.

3. Pidana mati selalu hanya diancamkan dan dijatuhkan untuk kejahatan berkategori berat/sangat serius, baik dilihat dari segi modus maupun 
dampak yang ditimbulkannya.

Adapun secara de facto, tidak dapat dipungkiri pula bahwa pidana mati pun masih terus terlihat ditegakkan melalui vonnis pengadilan serta eksekusinya dalam berbagai kasus. Misalnya dalam kasus-kasus narkoba, pembunuhan sadis-mutilatif, terrorisme dengan korban yang massifsporadis dan lain-lain.

Berdasarkan semua kenyataan di atas, maka betapapun kontroversialnya keberadaan pidana mati di Indonesia, secara yuridis formal ia tetap harus dipandang sebagai suatu sanksi hukum yang justified sekali gus legitimate. Paling tidak untuk saat sekarang ini.

\section{Kebijakan Regulasi Pidana Mati dalam RUU KUHP}

Meski dilihat dari segi apapun (baik de yure maupun de facto) pidana mati tetap sah berlaku, namun adanya berbagai pandangan kontroversial yang selalu menyertainya tersebut, tentu tidak dapat diabaikan begitu saja. Oleh karena itu, seiring dengan sedang berprosesnya upaya penal reform (pembaharuan hukum pidana) di Indonesia dewasa ini, kiranya menarik untuk dicermati bagaimana politik atau kebijakan RUU KUHP sebagai salah satu bentuk rancangan penal reform tersebut mengakomodir kontroversialitas pidana mati tadi dalam konsep hukumnya.

Sehubungan dengan hal di atas, di bawah ini akan dideskripsikan secara garis besar kebijakan mengenai pengaturan pidana mati dalam RUU KUHP mendatang sebagai berikut: ${ }^{17}$

1. Kedudukan pidana mati dalam stelsel pidana RUU KUHP

Dalam pasal 66 RUU disebutkan:

"Pidana mati merupakan pidana pokok yang bersifat khusus dan selalu diancamkan secara alternatif". Selanjutnya penjelasan pasal ini menyatakan: "Pidana mati dicantumkan dalam pasal tersendiri untuk menunjukkan bahwa jenis pidana ini benar-benar bersifat khusus. Jika dibandingkan dengan jenis pidana yang lain, pidana mati merupakan jenis pidana yang paling berat. Oleh karena itu, harus selalu diancamkan secara alternatif dengan jenis pidana lainnya yakni pidana penjara seumur hidup atau pidana penjara paling lama 20 (dua puluh) tahun".

${ }^{17}$ RUU KUHP yang dijadikan landasan analisis dalam tulisan ini adalah Rancangan KUHP Tahun 2005/2006 
2. Tujuan penjatuhan pidana mati Dalam pasal 87 dinyatakan:

"Pidana mati secara alternatif dijatuhkan sebagai upaya terakhir untuk mengayomi masyarakat". Selanjutnya penjelasan pasal ini menegaskan: "Dalam ketentuan pasal ini kembali ditekankan sifat kekhususan pidana mati yaitu hanya dapat dijatuhkan sebagai upaya terakhir untuk mengayomi masyarakat".

3. Ketentuan mengenai tatacara pelaksanaan (eksekusi) pidana mati dan modifikasinya

a. Pasal 88 yang terdiri atas 4 (empat) ayat menentukan hal-hal sebagai berikut:

Ayat (1) Pidana mati dilaksanakan dengan menembak terpidana sampai mati oleh regu tembak. Dalam penjelasan ayat ini, disebutkan pelaksanaan pidana mati dengan cara menembak terpidana adalah didasarkan pada pertimbangan bahwa sampai saat ini cara tersebut dinilai paling manusiawi. Dalam hal dikemudian hari terdapat cara lain yang lebih manusiawi daripada dengan cara menembak terpidana, pelaksanaan pidana mati disesuaikan dengan perkembangan tersebut.

Ayat (2) Pidana mati sebagaimana dimaksud pada ayat (1) tidak dilaksanakan di muka umum. Tidak ada penjelasan apapun terkait dengan ayat ini, hanya ditulis "cukup jelas". Padahal mestinya ada keterangan mengapa cara eksekusi tertutup tersebut yang digunakan, apakah hal itu mendukung ataukah sebaliknya terhadap upaya optimalisasi pencapaian tujuan pidana missal berupa general prevention.

Ayat (3) Pelaksanaan pidana mati terhadap wanita hamil atau orang yang sakit jiwa ditunda sampai wanita tersebut melahirkan atau orang yang sait jiwa tersebut sembuh. Dalam penjelasan ayat ini dikatakan bahwa penundaan tersebut dimaksudkan agar pelaksanaan pidana mati tidak megakibatkan terjadinya pembunuhan terhadap dua makhluk. Namun terhadap penundaan eksekusi pidana mati terhadap orang yang sakit jiwa tidak ada penjelasan dasar dan maksud tujuannya.

Ayat (4) Pidana mati baru dapat dilaksanakan setelah permohonan grasi bagi terpidana ditolak oleh Presiden. Dalam penjelasan ayat ini, dikatakan bahwa mengingat beratnya pidana mati dan tidak mungkin dapat diperbaiki lagi apabila ada kekeliruan, maka pelaksanaannya baru 
dapat dilakukan setelah Presiden menolak permohonan grasi orang yang bersangkutan. Hal ini sejalan dengan konvensi Safeguards Quaranteeing Protection on the Rights of those Facing the Death Penalty Economic and Social Council Resolution 1984 Tahun 50, adopted 25 May 1984 yang telah diratifikasi dan diikuti oleh Indonesia.

b. Pasal 89 yang terdiri atas 3 (tiga) ayat menegaskan hal-hal sebagai berikut:

Ayat (1) Pelaksanaan pidana mati dapat ditunda dengan masa percobaan selama 10 (sepuluh) tahun, jika:

a. reaksi masyarakat terhadap terpidana tidak terlalu besar;

b. terpidana menunjukkan rasa menyesal dan ada harapan untuk diperbaiki;

c. kedudukan terpidana dalam penyertaan tindak pidana tidak terlalu penting; dan

d. ada alasan meringankan.

Ayat (2) Jika terpidana selama masa percobaan sebagaimana dimaksud pada ayat (1) menunjukkan sikap dan perbuatan yang terpuji, maka pidana mati dapat diubah menjadi pidana seumur hidup atau pidana penjara paling lama 20 (dua puluh) tahun dengan Kepuitusan Menteri Hukum dan Hak Asasi Manusia.

Ayat (3) Jika terpidana selama masa percobaan sebagaimana dimaksud dalam ayat (1) tidak menunjukkan sikap dan perbuatan yang terpuji serta tidak ada harapan untuk diperbaiki, maka pidana mati dapat dilaksanakan atas perintah Jaksa Agung.

Penjelasan keseluruhan atas isi pasal 89 yang terdiri 3 ayat di atas menyebutkan bahwa dalam Kitab Undang-undang Pidana ini, pidana mati bukan sebagai salah satu jenis pidana pokok yang bersifat umum, tetapi lebih merupakan pidana yang bersifat khusus. Kekhususan tersebut ditunjukkan bahwa pidana mati diancamkan dan dijatuhkan secara sangat selektif. Dalam hubungan ini, hakim pertama-tama selalu mempertimbangkan secara mendalam apakah dalam kasus yang dihadapi dapat diterapkan pidana alternatif "penjara seumur hidup" ataupun "penjara 20 (dua puluh) tahun". Dalam hal masih terdapat keraguan mengenai kemungkinan penggunaan salah satu pidana alternatif tersebut untuk kasus yang bersangkutan, maka dalam ketentuan pasal ini dibuka kemungkinan bagi hakim untuk menjatuhkan "pidana mati bersyarat". Dalam hal syarat-syarat yang tercantum dalam pasal ini dipenuhi oleh 
terpidana selama masa penundaan 10 (sepuluh) tahun, maka Menteri Hukum dan Hak Asasi Manusia dapat mengubah pidana tersebut menjadi salah satu pidana alternatif. Dengan pola ini maka jelaslah bahwa Kitab Undang-undang Hukum Pidana ini ingin membatasi pelaksanaan pidana mati sesuai dengan perasaan keadilan yang berkembang dalam masyarakat. Adapun tenggang waktu masa percobaan 10 (sepuluh) tahun dalam pidana mati bersyarat ini adalah dihitung sejak permohonan grasi ditolak.

c. Pasal 90 menyatakan bahwa:

“Jika permohonan grasi terpidana mati ditolak dan pidana mati tidak dilaksanakan selama 10 (sepuluh) tahun bukan karena terpidana melarikan diri, maka pidana mati tersebut dapat diubah menjadi pidana seumur hidup dengan Keputusan Presiden".

Jika bunyi Pasal 90 di atas dikaitkan dengan penjelasan pasal itu sendiri maka terlihat adanya sebuah kejanggalan regulasi terutama yang berkait dengan siapa pejabat dan institusi mana yang dianggap memiliki wewenang untuk mengubah putusan pidana mati oleh hakim pengadilan menjadi pidana seumur hidup. Apakah Presiden melalui Keppres-nya ataukah melalui Surat Keputusan Menteri Kehakiman dan HAM. Kejanggalan aturan ini mengingat penjelaan pasal tersebut menyatakan:

"Dalam hal putusan hakim yang menjatuhkan pidana mati telah memperoleh kekuatan hukum tetap dan permohonan grasinya ditolak, namun pelaksanaan pidana mati tersebut tertunda selama 10 (sepuluh) tahun bukan karena terpidana melarikan diri, maka Menteri Kehakiman dan Hak Asasi Manusia berwenang untuk mengubah putusan pidana mati menjadi pidana penjara seumur hidup".

Berdasarkan beberapa pasal RUU KUHP di atas dapat diketahui bahwa pada prinsipnya pidana mati dalam konstruksi hukum pidana Indonesia mendatang tetap dipertahankan. Walaupun dengan status/ kedudukan yang sangat spesifik yakni sebagai pidana khusus dan eksepsional. Jadi tidak lagi sebagai pidana pokok bersifat umum seperti yang termaktub dalam pasal 10 huruf a KUHP yang berlaku sekarang.

Adapun latar belakang dari kebijakan pengaturan pidana mati yang bersifat khusus dan eksepsional tersebut sebagaimana dijelaskan oleh Pasal 66 jo. Pasal 87 RUU KUHP, adalah karena disadari bahwa pidana mati merupakan jenis sanksi hukum paling berat dibanding sanksi-sanksi lainnya. Oleh karena itu pengancaman dan penjatuhannya tidak boleh sembarangan (harus selektif). Dan oleh karena itu, politik pengancamannya 
pun ditegaskan yakni selalu dialternatifkan dengan pidana lain berupa penjara seumur hidup atau penjara maksimal 20 tahun. Hal ini dimaksudkan agar aparat terutama hakim yang menegakkan hukum pidana tidak terjebak untuk mudah menjatuhkan jenis sanksi ini tanpa pertimbangan matang terhadap keadilan hukum berbagai pihak yang terkait (termasuk terpidana) yang harus diwujudkan melalui putusannya. Sebab sebagai pidana terberat, hukuman mati ibaratnya adalah senjata pamungkas/andalan yang penggunaannya tentu harus bersifat hati-hati/ selektif dan benar-benar diyakini tidak ada pilihan lain saat itu untuk mengatasi kejahatannya kecuali dengan penjatuhan pidana mati tersebut. Dalam perspektif teori, politik pengancaman dan penjatuhan pidana mati yang demikian adalah selaras dengan asas fungsionalisasi hukum pidana sebagai ultimum remidium (sarana terakhir dalam upaya penanggulangan problem sosial berupa kejahatan). Bahkan menurut Van Bemmelen, urgensi asas ini tidak hanya penting diperhatikan pada saat melakukan kriminalisasi dan penalisasi, akan tetapi juga pada saat menerapkan undang-undang hukum pidana dalam praktik penegakan hukum. ${ }^{18}$

Dipertahankannya sanksi pidana mati dalam RUU KUHP, sekilas memang mengandung kesan bahwa konstruksi hukum pidana Indonesia mendatang cenderung dibangun atau bertolak dari ide dasar mengenai pentingnya perlindungan masyarakat semata. Hal tersebut bisa dimengerti mengingat jenis sanksi ini tentu sulit untuk dipandang sebagai konsep hukum yang berpihak pada kepentingan terpidana pelaku kejahatan. Sebab melalui pidana mati, ia justru dijustifikasi sekali gus dilegitimasi oleh hukum untuk dimatikan kehidupannya sehingga tidak berkesempatan untuk memperbaiki diri dari kesalahan/kejahatan yang terlanjur dilakukannya.

Kesan di atas juga semakin terlihat jika dikaitkan dengan ketentuan pasal 87 RUU dan penjelasannya yang menyatakan bahwa pidana mati secara alternatif dijatuhkan sebagai upaya terakhir untuk mengayomi masyarakat. Penegasan demikian memang bisa melahirkan persepsi bahwa eksistensi pidana ini tidaklah dimaksudkan untuk mendukung pencapaian tujuan-tujuan pemidanaan lain di luar tujuan melindungi

${ }^{18}$ J.M van Bemmelen, Hukum Pidana I: Hukum Pidana Materiel Bagian Umum (terjemahan), Bina Cipta, Jakarta, 1987, hlm. 13-14. Baca pula Muladi dan Barda Nawawi Arief dalam dua buku berbeda yakni Teori-Teori dan Kebijakan Pidana, Alumni, Bandung, 1992, hlm 33, serta Kapita Selekta Hukum Pidana, Alumni, Bandung, 1992, hlm. 102. 
masyarakat. Padahal dalam kebijakan hukum pidana mendatang telah digariskan bahwa selain untuk melindungi dan mengayomi masyarakat, penjatuhan pidana juga didasarkan dan diorientasikan pada upayaupaya untuk mewujudkan berbagai tujuan lain seperti membimbing dan membina terpidana agar kembali menjadi orang baik dan berguna di masyarakat, menyelesaikan konflik dan memulihkan keseimbangan sosial yang terguncang akibat terjadinya tindak pidana dan membebaskan rasa bersalah pada diri terpidana. ${ }^{19}$

Namun demikian, jika dicermati lebih mendalam kesan di atas tidaklah sepenuhnya benar. Sebab dengan adanya penegasan bahwa kedudukan pidana mati adalah sebagai pidana khusus dan eksepsional yang penjatuhannya harus sangat selektif dan benar-benar sebagai upaya terakhir, justru menunjukkan sebagai sebuah konsep hukum yang mengandung orientasi berupa perhatian/perlindungan kepada kepentingan calon terpidana (individualisasi pidana). Karena dengan konsep hukum tersebut, secara tidak langsung hakim seolah diperintahkan untuk terlebih dahulu mencari solusi pemidanaan lain sebelum menggunakan pidana mati. Artinya, penjatuhan pidana mati haruslah dipandang dan dilaksanakan sebagai alternatif/solusi paling akhir bagi penyelesaian suatu kejahatan. Bukan diutamakan, meskipun ia sebagai pidana pokok.

Selanjutnya, kebijakan pengaturan pidana mati yang tetap mempertimbangkan perlindungan terhadap kepentingan individu terpidana tersebut, juga dapat dilihat dalam rancangan Pasal 88 sampai dengan Pasal 90 tentang tatacara pelaksanaan (eksekusi) pidana mati.

${ }^{19}$ Lihat Konsep Pasal 54 RUU KUHP. Dalam Naskah KUHP paling baru (2007) sedang dirancang satu tujuan pemidanaan lagi yakni memaafkan terpidana. Konsep ini dimaksudkan sebagai penjabaran ide tentang Rechterlijk Pardoon yang juga dirancang dalam Pasal 55 ayat (2) RUU KUHP mendatang, di mana berdasarkan ketentuan ini, hakim boleh/diberi kewenangan untuk tidak menjatuhkan pidana (baca: memaafkan) kepada seorang terdakwa yang diadilinya. Meskipun dalam persidangan, pada diri terdakwa tersebut telah terbukti tindak pidana yang didakwakan serta terbukti pula kesalahannya. Rechterlijk Pardoon ini bisa diterapkan jika tindak pidananya bersifat sangat ringan dan ada kondisi tertentu pada diri pelaku terkait dengan masalah keadilan dan kemanusiaan, serta ada pertimbangan hakim bahwa justru dengan pemidanaan tersebut, berbagai tujuan penjatuhan pidana diperkirakan tidak dapat dicapai/diwujudkan. Lebih jelas mengenai hal ini dapat pula dibaca Barda Nawawi Arief, "Penegakan Hukum Pidana dalam Konteks Sistem Hukum dan Pembangunan Nasional," makalah disampaikan dalam Studium Generale diselenggarakan oleh Departemen Pidana Fakultas Hukum UII Yogyakarta 15 Mei 2007, hlm. 6-12. 
Konsep hukum dalam 3 pasal yang juga mengandung aturan tentang modifikasi pidana mati ini, pada intinya menegaskan beberapa rancangan kebijakan sebagai berikut:

1. Pelaksanaan pidana mati harus ditunda sehubungan dengan adanya kondisi tertentu yang dialami terpidana. Misalnya karena sedang hamil atau sakit jiwa hingga yang bersangkutan telah melahirkan anak atau sembuh dari penyakit jiwanya (vide Pasal 88 ayat 3). Ketentuan yang demikian adalah menggambarkan suatu konsep hukum yang sekalipun dengan pidana mati itu tujuan akhirnya untuk melindungi dan mengayomi masyarakat, namun tetap memperhatikan kepentingan si terpidana sebagai pelaku kejahatan.

2. Bagi terpidana mati yang mengajukan grasi kepada Presiden, ekeskusi/ pelaksanaan pidananya harus memperhatikan syarat akhir bersifat mutlak yaitu berupa adanya Keputusan Presiden yang berisi penolakan grasi terpidana (vide Pasal 88 ayat 4). Ketentuan demikian mengandung makna bahwa hukum tidak boleh terburu-buru mengakhiri kehidupan si terpidana mati. Dengan kata lain hukum semaksimal mungkin harus tetap memperhatikan kepentingan terpidana yang sedang berusaha mencari upaya untuk meringankan hukumannya melalui grasi agar dapat memiliki kesempatan untuk memperbaiki diri. Walaupun sesungguhnya secara yuridis formal telah ada putusan pengadilan berkekuatan tetap yang memberi legalitas bagi tindakan eksekusi;

3. Dengan syarat-syarat tertentu, eksekusi atas pidana mati terhadap seseorang yang perkaranya telah memperoleh putusan hukum berkekuatan tetap, dimungkinkan untuk ditunda bahkan dirubah putusannya menjadi penjara seumur hidup atau penjara maksimum 20 tahun dengan masa percobaan 10 tahun (vide pasal 89 ayat 1 dan ayat 2). Ketentuan modifikasi putusan pidana mati yang seperti ini sering disebut dengan istilah Pidana Mati Bersyarat. Tidak dapat dipungkiri bahwa konsep hukum yang demikian tentu sangat menggambarkan adanya wacana hukum yang memberikan perhatian/ perlindungan kepada terpidana pelaku kejahatan. Hanya saja ketentuan mengenai lamanya masa percobaan yang 10 tahun untuk menilai serta menunda bahkan akhirnya merubah putusan pidana mati menjadi pidana lainnya tersebut, perlu ditinjau ulang. Sebab dengan ilmu bantu lain yang terkait dengan penegakan hukum pidana seperti psikologi kriminal, sesungguhnya rentang waktu yang dibutuhkan 
untuk menilai ada tidaknya perubahan perilaku seorang terpidana mati dapat lebih diperpendek jangkanya (tidak harus 10 tahun). Sehingga penderitaan akibat double sentenced atau bahkan multi sentenced seperti yang dialami para terpidana mati selama ini (karena terlalu lama menunggu masa eksekusi yang tidak pasti), dapat dihindari atau setidaknya diminimalisasi.

4. Dengan syarat tertentu pula, modifikasi atau perubahan status hukum putusan pidana mati menjadi pidana penjara seumur hidup, juga dapat dilakukan meskipun putusan pidana mati atas seseorang telah berkekuatan tetap. Bahkan sekalipun pula grasi yang diajukan terpidana ditolak tegas oleh Presiden. Syaratnya ialah jika setelah permohonan grasi terpidana mati ditolak, namun eksekusi pidananya tidak dijalankan oleh petugas hingga selama 10 tahun lebih tanpa alasan yang benar dan jelas dari petugas eksekutor yang lalai tersebut (vide Pasal 90).

Adanya sejumlah kebijakan regulasi hukum tentang pidana mati dalam RUU KUHP di atas, di mana pada satu sisi mencerminkan wacana pentingnya perlindungan terhadap kepentingan masyarakat, namun pada sisi yang lain juga tidak mengabaikan wacana perlindungan kepentingan individual terpidana, sekali lagi hal itu adalah selaras dengan konstruksi/ bangunan hukum pidana modern yang dicitakan oleh bangsa Indonesia di masa mendatang yaitu hukum pidana yang berbasis pada ide Keseimbangan Mono-Dualistik atau Daad-Daader Strafrecht. ${ }^{20}$

Namun demikian, di samping rancangan kebijakan yang sudah terlihat baik di atas, patut pula dikemukakan di sini bahwa konsep tersebut sesungguhnya masih mengandung beberapa kelemahan sebagai berikut: 1. Kebijakan yang berkait dengan pelaksanaan pidana mati yang tidak boleh dilakukan di muka umum, tampaknya perlu ditinjau ulang. Sebab jika hal demikian diterapkan terus seperti yang sudah berjalan selama ini berdasar UU No.2/Pnps Tahun 1964, maka tujuan pemidanaan berupa prevention of crime (pencegahan kejahatan) terutama yang bersifat general prevention (pencegahan diulanginya kejahatan seperti terpidana oleh masyarakat luas), menjadi sulit diharapkan dapat terwujud. Karena publik tidak pernah melihat dan mengetahui secara pasti bagaimana dahsyatnya sebuah kematian yang timbul dalam

${ }^{20}$ Lihat kembali arti tentang konstruksi hukum pidana yang berbasis Ide Keseimbangan Mono Dualistik atau Daad-daader Strafrecht pada catatan kaki no 1 di atas 
eksekusi pidana mati bersifat tertutup.

2. Ada kerancuan dasar hukum yang harus digunakan untuk melaksanakan kebijakan modifikasi pidana mati menjadi pidana penjara seumur hidup. Karena Pasal 90 RUU menegaskan bahwa hal itu harus dengan Keputusan Presiden. Namun Penjelasan dari pasal 90 itu sendiri menegaskan bahwa pelaksanaan modifikasi tersebut cukup dengan Keputusan Menteri Kehakiman dan HAM. Oleh karean itu antara pasal dengan penjelasannya harus diselaraskan isinya. Apakah dasar hukum untuk memodifikasi pidana mati tersebut harus dengan Keputusan Presiden (Keppres) ataukah cukup dengan Keputusan Menteri Hukum dan HAM.

\section{Perspektif Komparatif Menurut Hukum Islam}

Dalam hukum Islam, keberadaan pidana mati sebagai sanksi hukum disebutkan dengan berbagai macam istilah yang diancamkan untuk beberapa kasus jarimah atau kejahatan tertentu. Misalnya:

1. Pidana qishash yang diancamkan pada kejahatan pembunuhan bersifat/secara sengaja (Yaa ayyuhalladzina aamanu kutiba 'alaikumul qishashu fil qotlaa ...) ${ }^{21}$

2. Pidana mati melalui cara Umum atau cara Salib yang diancamkan pada kejahatan perampokan yang berakibat terbunuhnya si korban (Innamaa jazaaulladzina yuhaaribuunallaha wa rasuulahu wa yas'auna fil ardli fasaadan an-yuqattaluu au yushallabuu ....) ${ }^{22}$

3. Pidana rajam, yaitu melalui cara terpidana ditanam tubuhnya separuh badan kemudian dilempari dengan batu hingga menemui ajalnya) yang diancamkan pada kejahatan zina bersifat muhshan ( pezina yang sudah punya suami/istri sah) ${ }^{23}$

\footnotetext{
${ }^{21}$ Lihat Al-Qur'an Surat Al-Baqarah ayat 178

${ }^{22}$ Lihat Al-Qur'an Surat Al-Maaidah ayat 33

${ }^{23}$ Lihat Hadits Rasulullah SAW riwayat Abu Daud yang berbunyi: Khudzuu 'annie (3x), al-bikru bil bikri jaldatu mi'atin wa nafyu sanatin, wats-tsayyibu bits-tsayyibi rajamun bil hijaarati hattal mauti. Artinya: Ambillah hukum dariku (wahai ummatku) yaitu bahwa pezina laki-laki dan perempuan yang ghoiru mukhshan (belum beristri/bersuami) hukumannya adalah dicambuk seratus kali dan ditambah dengan hukumaN pembuangan/pengasingan selama satu tahun. Sedangkan untuk pezina mukhshan (yang telah bersuami/beristri) hukumannya adalah dirajam hingga mati.
} 
4. Pidana Mati yang diancamkan pada kejahatan riddah yaitu perbuatan seorang muslim yang keluar meninggalkan agamanya dan kemudian melakukan desersi (menyeberang kepada kelompok musuh Islam sehingga dapat mengancam/membahayakan eksistensi Islam dan ummat muslim) ${ }^{24}$

Berdasarkan ketentuan al-qur'an maupun hadits di atas, terlihat bahwa menurut ajaran Islam pengancaman sanksi pidana mati adalah hanya diperuntukkan bagi kejahatan-kejahatan tertentu yang bersifat serius. Seperti pembunuhan sengaja tanpa alasan sah, pengkhianatan dalam kehidupan masyarakat muslim (riddah desersif) dan lain sebagainya. Bandingkan ketentuan hukum pidana Islam ini dengan ketentuan KUHP seperti pasal 340 tentang pembunuhan berencana, pasal 104 tentang makar dengan maksud untuk membunuh presiden atau wakil presiden dan pasal 111 tentang pengkhianatan terhadap negara pada saat perang atau tentang kejahatan terrorisme yang korbannya massif serta sporadis dan lain-lain.

Adapun filosofi dan tujuan yang mendasari pengancaman pidana mati menurut Islam, dalam al-qur'an surat Al-Baqarah : 179 disebutkan konsep ajarannya yang berbunyi sebagai berikut: "Wa lakum fil qishaashi hayaatun yaa ulil albaab".

Berdasarkan ayat di atas diketahui bahwa maksud tujuan ditetapkannya ancaman pidana qishash ( pidana mati) terhadap kejahatan pembunuhan (sebagai contoh) adalah agar supaya jaminan hak hidup manusia (hayaatun) sebagai salah satu HAM yang paling mendasar dapat diwujudkan. Dasar logikanya ialah jika setiap orang mau dan mampu berpikir (ulil albab) untuk memahami bahwa siapapun yang membunuh pasti akan berakibat dirinya terbunuh (melalui penerapan sanksi pidana qishash), maka hal demikian ini tentu akan menjadi daya prevensi internal bagi para calon pelaku pembunuhan. Sebab siapapun pasti ingin

${ }^{24}$ Lihat Hadits Rasulullah SAW riwayat Bukhori-Muslim yang berbunyi: Man baddala dienahu faqtuluuhu. Artinya, barangsiapa (seorang muslim) sengaja meninggalkan/mengganti agamanya dengan agama lain maka bunuhlah dia. Cermati pula hadits lain dengan rawi yang sama yang berbunyi: Laa yahillu daamun imri'in muslimin illa min tsalaatsin, ... at-taariku li diinihi al mufaariqi lil jamaa'ati. Artinya: Dihalalkan membunuh (sebagai pelaksanaan sanksi pidana mati -pen.) atas tiga kelompok orang yang berbuat sebagai berikut: (1) ... (2) ... dan (3) orang muslim yang keluar meninggalkan agamanya dan kemudian melakukan desersi (menyeberang kepada kelompok musuh Islam sehingga dapat mengancam/membahayakan eksistensi Islam dan ummat muslim). 
menghindari kerugian berupa terbunuhnya diri sendiri akibat penerapan hukum qishash tersebut. Jika sudah demikian maka tidak akan ada lagi orang membunuh dan itu berarti hak hidup/nyawa setiap orang akan lebih terjamin keberadaannya. ${ }^{25}$

Selanjutnya, untuk memahami bagaimana Islam memberikan justifikasi terhadap keberadaan pidana mati yang hakekatnya merupakan perampasan nyawa seseorang oleh seseorang yang lain (c.q penguasa melalui aparat eksekutornya), dan bagaimana pula Islam memandang posisi keberadaan sanksi pidana mati itu sendiri, kiranya patut dicermati ketentuan al-Qur'an surat Al-Baqarah: 178 yang berbunyi sebagai berikut:

"Yaa ayyuhalladziina aamanuu kutiba 'alaikumul qishaashu fil qatlaa. Alhurru bil hurri wal 'abdu bil 'abdi wal untsa bil untsa. Fa man 'ufiya lahuu min akhiehi syai'un fat-tibaa'un bil ma'ruufi wa adaa'un ilaihi bi ihsaanin. Dzaalika takhfiefun min rabbikum wa rahmatun. Fa man i'tadaa ba'da dzaalika falahuu 'adzaabun aliem".

Menurut Sayyid Sabieq, ${ }^{26}$ ayat yang merupakan referensi utama untuk melihat konsep Islam mengenai pidana mati tersebut mencakup berbagai kandungan makna/hikmah sebagai berikut:

1. Qishash ( pidana mati) merupakan sanksi hukum yang telah ditetapkan oleh Allah SWT bagi pelaku pembunuhan, yang pelaksanaannya diwajibkan atau dibebankan kepada manusia ( orang-orang yang beriman melalui pemerintahan yang representatif). Jadi ketika ada orang melanggar hak hidup orang lain dengan membunuh (secara sengaja tanpa alasan hak), Allah sebagai pemilik hakiki atas kehidupan seluruh ummat manusia telah memberikan semacam delegasi kepada manusia ( penguasa representatif) melalui hukum qishash ini agar orang yang membunuh tersebut dibunuh atau dirampas pula hak hidupnya sebagai balasan. Dengan demikian tidak ada alasan untuk mengatakan bahwa penjatuhan dan pelaksanaan pidana mati tidak sah karena yang paling berhak

${ }^{25}$ Ali Ash-Shaabuni, Rawaai'ul Bayaani Tafsieru Aayaatil Ahkaami, Daaru Ihyaai At-Tuuraatsi Al-'Araabi, Damaskus, 1980, hlm 170. Baca pula Fikri Ahmad 'Akkaadz, Falsafatu al-'Uquubati fis-Syari'ati al-Islaamiyyati, Syirkah Maktabaatu 'Akkaadhi linNasyri wat-Tauzi'i, al-Mamlakatu al-'Arabiyyatu as-Su'uudiyyah, tanpa tahun, hlm 171-180. Bandingkan pula penjelasan mengenai filosofi dan tujuan pidana qishash di atas dengan teori Psychologischen Zwang yang dikemukakan oleh von Fauerbach sebagaimana dikutip oleh Moeljatno, Asas-Asas Hukum Pidana, Bina Aksara, Jakarta, 1993, hlm. 25.

${ }^{26}$ Sayyid Saabiq, Fikih Sunnah, Al-Ma'arif, Bandung, 1987, hlm.13-29. 
mematikan suatu kehidupan ialah sang pemberi kehidupan itu sendiri yakni Tuhan Allah SWT.

2. Penggunaan kata qishash untuk menyebutkan sanksi hukum yang berupa pidana mati, sesungguhnya mengandung ajaran tentang equality befor the law (persamaan di hadapan hukum). Karena kata "qishash" yang memiliki arti "tattabi'ul atsaar" (artinya, mengikuti/menyamakan sesuatu hal kepada hal lain yang telah terjadi sebelumnya), menunjukkan makna bahwa melalui konsep qishash Islam mengajarkan tentang perlakuan secara sama yang dikenakan oleh hukum terhadap seseorang yang telah berbuat sesuatu hingga berakibat hilangnya nyawa orang lain. Perlakuan secara sama yang dimaksud dalam hal ini ialah orang yang telah berbuat membunuh tersebut harus diikuti pula perbuatannya itu dengan cara yang sama yakni di bunuh. Jadi barang siapa membunuh ia dibunuh pula (siapapun dia). Konsep ini berarti hukum Islam memandang dan memperlakukan secara sama terhadap setiap orang. ${ }^{27}$

3. Sekalipun kedudukan qishash (baca: pidana mati) dalam pandangan Islam adalah sebagai pidana pokok, akan tetapi fungsionalisasinya harus ditempatkan sebagai alternatif terakhir (bukan pilihan utama apalagi harus pertama). Karena dalam Islam hal pertama yang dianjurkan pada korban atau keluarganya ialah menempuh sikap memaafkan pelaku kejahatan baik disertai dengan tuntutan diyat (ganti rugi untuk korban/keluarganya) atau pun memaafkan pelaku secara mutlak tanpa tuntutan apapun. Ada sejumlah ayat al-qur'an dan hadits nabi yang menjadi basis ajaran pemaafan pidana qishash (mati) ini, antara lain yaitu:

a. Fa man 'afaa wa ashlaha fa ajruhuu 'alallaahi ${ }^{28}$

b. Wa anta'fuu aqrabu littaqwaa ${ }^{29}$

c. ... Fa man 'ufiya lahuu min akhiehi syai'un fattibaa'un bil ma'ruufi wa adaa'in ilaihi bi ihsaanin ...al-ayat ${ }^{30}$

d. Maa rufi'a ilaihi syai'un fii qishaashin illa umira bihi bil 'afwi (Al

${ }^{27}$ Ahmad Fathi Bahantsi, Al-Qishaashu fil Fighi al-Islaamie, asy-Syirkah al'Araabiyyah lit-Tibaa'ah wan-Nasyr, Kairo, 1964, Hlm 11. Baca pula Muhammad Rawwas Qol'ahjie, Mu'jam al-Lughat al-Fuqahaa' ('Arabie - Inklizie - Afransie), Daar an-Nafaaisi, Beirut, 1996, hlm. 287.

${ }^{28}$ Lihat Q.S As-Syuura: 40

${ }^{29}$ Lihat Q.S Al-Baqarah: 227

${ }^{30}$ Lihat Q.S Al-Baqarah: 178 
Hadits).Man qutila lahu qatielun fahuwa bi khoirin nadharaini baina an ya'khudza ad-diyyata wa baina an ya'fuwa (Al-Hadits).

4. Diajarkannya sikap memaafkan sebagai pilihan utama tersebut di atas adalah karena hukum Islam yang merupakan rahmatan lil 'alaamien, pada satu sisi ingin membangun watak/karakter bijak manusia (terutama dalam hal ini korban/keluarga korban) dengan landasan sikap saling mengasihi melalui media memaafkan. Bukan dengan landasan kemarahan berupa tuntutan balas dendam. Adapun sikap memaafkan tersebut dianggap sebagai watak/karakter bijak karena memaafkan itu berarti melepaskan hak untuk menuntut, yang tidak semua orang mampu melakukannya. Sedang pada sisi lain, dengan konsep al'afwu (pemaafan pidana qishash) ini hukum Islam mengajarkan betapapun jahatnya si pelaku ia tetap perlu diberi perhatian oleh hukum dengan diberi kesempatan untuk memperbaiki diri melalui pintu pemaafan oleh korban tersebut.

5. Bandingkan konsep pemaafan pidana qishash dalam Islam ini (yang berarti qishash justru dikonsepkan sebagai pidana alternatif akhir), dengan konsep eksistensi pidana mati dalam RUU KUHP mendatang yang juga ditempatkan sebagai pidana khusus bersifat eksepsional (baca: sebagai sanksi alternatif akhir) dengan berbagai syarat dalam ekseskusinya yang merupakan modifikasi atas pidana mati tersebut.

\section{Penutup}

Kebijakan RUU KUHP yang tetap mempertahankan eksistensi pidana mati demi untuk mengayomi masyarakat, pada prinsipnya sesuai dengan spirit ajaran HAM paling mendasar sekaligus juga untuk melindungi kehidupan manusia secara luas (masyarakat).

Kebijakan pencantuman pidana mati dalam RUU KUHP yang dirancang sebagai pidana khusus dan hanya diperuntukkan sebagai ancaman terhadap jenis-jenis kejahatan tertentu yang bersifat serius dengan aturan penerapan yang sangat selektif, adalah sudah tepat. Mengingat sifat dan bobot jenis pidana ini merupakan sanksi hukum paling berat. Hal ini juga sejalan dengan konsep Islam yang meskipun mencantumkan qishash sebagai salah satu jenis pidana pokok, namun implementasinya justru ditekankan agar hanya digunakan sebagai sarana paling akhir setelah upaya-upaya lain (terutama pemaafan) tidak mampu menyelesaikan problem hukum yang dapat dikenai ancaman pidana ini. 
Ajaran demikian menunjukkan bahwa konsep qishash dalam Islam sesungguhnya mengandung dimensi/orientasi perhatian terhadap kepentingan pelaku kejahatan (offender) sebagaimana hal ini kemudian juga terlihat dalam kebijakan pengaturan RUU KUHP tentang modifikasi pidana mati (pidana mati bersyarat).

Kebijakan tata cara eksekusi pidana mati dalam RUU KUHP yang menyatakan tidak boleh dilakukan di muka umum, perlu ditinjau ulang dan dirubah sebaliknya. Karena konsep yang yang demikian justru dapat menghambat tercapainya tujuan pencantuman dan penjatuhan pidana mati itu sendiri terutama yang berupa prevention of crime (c.q general prevention).

\section{Daftar Pustaka}

Alqur'anul Kariem

Arief, Barda Nawawi, Penegakan Hukum Pidana dalam Konteks Sistem Hukum dan Pembangunan Nasional, Makalah disampaikan dalam Studium Generale diselenggarakan oleh Departemen Pidana Fakultas Hukum UII Yogyakarta. tanggal 15 Mei 2007.

, Pokok-Pokok Pemikiran (Ide Dasar) Asas-Asas Hukum Pidana Nasional, Makalah dalam Seminar tentang Asas-Asas Hukum Pidana Nasional, Diselenggarakan oleh BPHN Dept. Kehakiman dan HAM RI Jakarta bekerjasama dengan Fakultas Hukum UNDIP Semarang, tanggal 26-27 April 2004.

, Bunga Rampai Kebijakan Hukum Pidana, Citra Aditya Bhakti, Bandung, 2002.

'Akkaadz, Fikri Ahmad, Falsafatu al-'Uquubati fis-Syari'ati al-Islaamiyyati, Syirkah Maktabaatu 'Akkaadhi lin-Nasyri wat-Tauzi'i, alMamlakatu al-'Arabiyyatu as-Su'uudiyyah, tanpa tahun.

Ash-Shaabuni, Ali, Rawaai'ul Bayaani Tafsieru Aayaatil Ahkaami, Daaru Ihyaai At-Tuuraatsi Al-'Araabi, Damaskus, 1980.

Bahantsi, Ahmad Fathi, Al-Qishaashu fil Fiqhi al-Islaamie, asy-Syirkah al'Araabiyyah lit-Tibaa'ah wan-Nasyr, Kairo, 1964.

Bemmelen, J.M van, Hukum Pidana I: Hukum Pidana Materiel Bagian Umum (terjemahan), Bina Cipta, Jakarta, 1987.

Faisal, M., Penjatuhan Pidana Mati dan Pengaruhnya terhadap Tingkat Kejahatan Narkoba di Wilayah Hukum PN Tangerang, Skripsi S-1, Fakultas Hukum UII Yogyakarta, 2006. 
Hamzah, Andi, Sistem Pidana dan Pemidanaan Indonesia, Pradnya Paramita Jakarta, 1993. dan Sumangelipu, Pidana Mati di Indonesia Di Masa lalu, Kini dan Di Masa Depan, Ghalia Indonesia, Jakarta, 1984.

Kholiq, M. Abdul, Penjatuhan Pidana Mati dalam Rangka Penegakan Hukum dan Eksistensinya dalam Pembaharuan KUHP Nasional, Skripsi S-1, Fakultas Hukum UII Yogyakarta, 1991.

Poernomo, Bambang, Ancaman Pidana Mati dalam Hukum Pidana di Indonesia, Liberty, Yogyakarta, 1982.

Moeljatno, Asas-Asas Hukum Pidana, Bina Aksara, Jakarta, 1987.

Muladi dan Arief, Barda Nawawi, Teori-Teori dan Kebijakan Pidana, Alumni, Bandung, 1992. , Kapita Selekta Hukum Pidana, Alumni, Bandung, 1992

Muzayyanah, Pidana Mati Ditinjau dari Pancasila, Majalah "MasalahMasalah Hukum, Fakultas Hukum Universitas Diponegoro (UNDIP) Semarang, edisi No.2 Tahun 1991.

Qol'ahjie, Muhammad Rawwas, Mu'jam al-Lughat al-Fuqahaa' ('ArabieInklizie - Afransie), Daar an-Nafaaisi, Beirut, 1996.

Saabiq, Sayyid, Fikih Sunnah, Al-Ma'arif, Bandung, 1987.

Sahetapy, J.E, Suatu Studi Khusus Mengenai Ancaman Pidana Mati terhadap Pembunuhan Berencana, Rajawali, Jakarta, 1982.

Saleh, Roeslan, Masalah Pidana Mati, Aksara Baru, Jakarta, 1978.

Soedarto, Suatu Dilemma dalam Pembaharuan Sistem Pidana Indonesia dalam Kumpulan Pidato Pengukuhan Guru Besar Fakultas Hukum, UNDIP, Semarang, Badan Penerbit Universitas Diponegoro, Semarang, 1994. , Hukum dan Hukum Pidana, Alumni, Bandung, 1986

UNISIA edisi No. 4/XI Tahun 1989, Topik Utama mengenai “Diskusi Hukuman Mati"

Wignjosoebroto, Soetandyo, Penerapan Pidana Mati: Sebuah Kontroversi dari Perspektif Hak-Hak Asasi Manusia, Makalah dalam Simposium Nasional bertema Perspektif terhadap Pidana Mati di Indonesia, diselenggarakan oleh Pusat Kajian Sistem Peradilan Pidana Fakultas Hukum Universitas Tujuh Belas Agustus (UNTAG) Semarang tanggal 14 Agustus 2003.

Zainal, Muhadi, Pidana Mati Dihapuskan atau Dipertahankan?, Hanindita Offset, Yogyakarta, 1984

Kitab Undang-Undang Hukum Pidana (KUHP)

RUU KUHP Naskah Rancangan 2005/2006 
UU No. 2/1964 tentang Tatacara Pelaksanaan Hukuman Mati Di Lingkungan Peradilan Umum dan Peradilan Militer

UU No. 5/1997 tentang Psikotropika

UU No. 22/1997 tentang Narkotika

UU No. 31/1999 jo. UU No. 20/2001 tentang Pemberantasan Tindak Pidana Korupsi

UU No. 26/2000 tentang Pengadilan HAM

UU No. 15/2003 tentang Pemberantasan Tindak Pidana Terorisme 